\title{
Priming of Cytotoxic T Lymphocytes by DNA Vaccines: Requirement for Professional Antigen Presenting Cells and Evidence for Antigen Transfer from Myocytes
}

\author{
Tong-Ming Fu, Jeffrey B. Ulmer, Michael J. Caulfield, \\ R. Randall Deck, Arthur Friedman, Su Wang, Xu Liu, \\ John J. Donnelly, and Margaret A. Liu \\ Department of Virus and Cell Biology, Merck Research Laboratories, \\ West Point, Pennsylvania, U.S.A.
}

\begin{abstract}
Background: MHC class I molecule-restricted cytotoxic T-lymphocyte (CTL) responses are induced following either intramuscular (i.m.) injection of a DNA plasmid encoding influenza virus nucleoprotein (NP) or transplantation of myoblasts stably transfected with the NP gene, the latter indicating that synthesis of NP by myocytes in vivo is sufficient to induce CTL. The present study was designed to investigate the role of muscle cells and involvement of professional antigen-presenting cells (APCs) in priming CTL responses following DNA vaccination.

Materials and Methods: Parent $\rightarrow$ Fl bone marrow (BM) chimeric mice were generated whose somatic cells include muscle cells bearing both parental MHC haplo-
\end{abstract}

types, while their professional APCs express only the donor MHC haplotypes.

Results and Conclusions: Upon injection of NP DNA, or after infection with influenza virus, CTL responses generated in the chimeras were restricted to the donor MHC haplotype. Thus cells of BM lineage were definitively shown to be responsible for priming such CTL responses after infection or DNA immunization. Moreover, expression of antigen by muscle cells in BM chimeric mice after myoblast transplantation is sufficient to induce CTL restricted only by the MHC haplotype of the donor BM. This indicates that transfer of antigen from myocytes to professional APCs can occur, thus obviating a requirement for direct transfection of BM-derived cells.

\section{INTRODUCTION}

Intramuscular (i.m.) injection of DNA plasmids encoding protein antigens has been demonstrated to induce MHC class I-rectricted cytotoxic T-lymphocyte (CTL) and antibody (Ab) responses, and to protect against subsequent challenge in certain disease models, with the i.m. route of immunization appearing most effective

Address correspondence and reprint requests to: Margaret A. Liu, Department of Virus and Cell Biology, WP16-101, Merck Research Laboratories, West Point, PA 19486, U.S.A. Tel: (215) 652-3535; Fax: (215) 652-7320; e-mail: margaret_liu@merck.com. for inducing protective CTL responses (1-3). We previously demonstrated the efficacy of DNA vaccines in vivo by showing that i.m. injection of mice with plasmid DNA encoding nucleoprotein (NP) from influenza virus A/PR/8/34 (H1Nl) provided protection against cross-strain challenge with $\mathrm{A} / \mathrm{HK} / 68$ (H3N2) (3). CTL responses specific for an $\mathrm{H}-2 \mathrm{~K}^{\mathrm{d}}$-restricted epitope (residues 147-155), an $\mathrm{H}-2 \mathrm{~K}^{\mathrm{k}}$-restricted epitope (residues 50-57), and an $\mathrm{H}-2 \mathrm{D}^{\mathrm{b}}$-restricted epitope (residues 366-374), were observed after NP DNA immunization of $\mathrm{BALB} / \mathrm{C}\left(\mathrm{H}-2^{\mathrm{d}}\right), \mathrm{C} 3 \mathrm{H}\left(\mathrm{H}-2^{\mathrm{k}}\right)$, and $\mathrm{C} 57 \mathrm{BL} / 6\left(\mathrm{H}-2^{\mathrm{b}}\right)$ mice, respectively $(3-5)$. It 
has been established that $\mathrm{CD}^{+} \mathrm{CTL}$ recognition generally requires intracellular processing of endogenously synthesized proteins for presentation of antigenic peptides by MHC class I molecules $(6,7)$. The cellular mechanism that accounts for the class I-restricted processing and presentation of antigens synthesized after i.m. DNA immunization, however, has not been elucidated.

Several lines of evidence suggested that muscle cells may play a role in the generation of CTL after i.m. injection of DNA. First, when plasmid DNA encoding reporter enzymes was injected into various organs, muscles expressed higher levels of protein than did other tissues when directly injected (e.g., skin, liver, brain, etc.) (8). Second, i.m. injection of NP DNA yielded better cell-mediated protection against cross-strain virus challenge than did intradermal injection of the same plasmid (1). Finally, transplantation of myoblasts stably transfected with DNA encoding NP was able to induce CTL responses and protective cross-strain immunity in histocompatible mice (4). In this latter experiment, production of NP antigen should occur exclusively in muscle cells. Thus, NP synthesis by myocytes alone appears to be sufficient for the induction of protective CTL responses. These observations raised the possibility that myocytes could function as antigen-presenting cells (APCs) for induction of MHC class I-restricted CTL responses by DNA immunization. Although myocytes can present antigen in the context of MHC molecules as shown by their ability to present antigens to $\mathrm{T}$ cells in culture (9) and to serve as targets for MHC class I-restricted CTL in vitro (4), they lack adhesion/costimulatory molecules (10) thought to be required for priming CTL responses. Therefore, other mechanisms, such as direct transfection of other cell types (e.g., BM-derived professional APCs) and antigen transfer from antigen-producing myocytes to bone marrow (BM)-derived APCs, as implicated in "cross-priming" experiments (11), must be considered.

The present study was designed to assess the respective contributions of muscle cells and BMderived APCs, i.e., professional APCs, in the induction of class I-restricted CTL responses after i.m. DNA injection by using parent $\rightarrow$ Fl BM chimeric mice. Here we demonstrate definitively that induction of CTL responses following DNA immunization is restricted by the haplotype of the donor BM cells, indicating that BM-derived professional APCs are responsible for direct induction of MHC class I-restricted CTL. Moreover, when production of NP was confined to the mus- cle cells in situ, this was sufficient to elicit CTL which likewise were restricted by the MHC haplotype of the donor BM cells. These results demonstrate that antigen transfer from muscle cells to professional APCs occurs in vivo, and such transfer may explain the observations to date for DNA vaccines injected i.m. (vide supra). Furthermore, we show that, in the case of respiratory infection with influenza virus, antigen presentation leading to induction of CTL responses was similarly restricted to the MHC haplotype of professional APCs.

\section{MATERIALS AND METHODS}

\section{DNA Constructs}

The expression vector used in the study, VlJa, was derived from the vector $\mathrm{V} 1 \mathrm{~J}$, which has been described previously (12). Briefly, it is a pUC19based plasmid that contains the human cytomegalovirus immediate early gene enhancer and promoter, the intron A sequence, multiple restriction sites (BglII, KpnI, EcoRV, EcoRI, SalI, and NotI) for cloning the gene of interest, and the bovine growth hormone polyadenylation signal sequence. The NP gene from influenza virus A/PR/8/34 (H1N1) was cloned into the BglII and SalI sites of VlJa vector (named NP DNA). Generation of NPmut DNA is described elsewhere (5). The plasmid DNA used for immunization was purified from $E$. coli by a modified alkaline lysis procedure, and DNA was banded twice in $\mathrm{CsCl}_{2}$ gradient.

\section{Animals}

Four- to eight-week-old female mice were purchased from Charles River Laboratories (Raleigh, NC) or Jackson Laboratory (Bar Harbor, ME). The animals were maintained in the animal facility of Merck Research Laboratories at West Point, PA. All experiments were performed in accordance to the procedures issued by the Institutional Animal Care and Use Committee.

\section{Generation of Chimera Mice}

Chimeras were prepared by a modification of the method reported by Huang et al. (13). BM cells harvested from the femurs of donor mice were depleted of $\mathrm{T}$ cells by incubation with rat monoclonal antibodies to CD2, CD4, CD8, and Thy 1.2, followed by "panning" on plates previously coated with goat anti-rat Ig (14). After two 
rounds of panning, the nonadherent cells $(2-4 \times$ $10^{6}$ cells/mouse) were resuspended in PBS and injected i.v. into $\mathrm{Fl}$ recipient mice that had been irradiated with approximately $10 \mathrm{~Gy}$ from a ${ }^{137} \mathrm{Cs}$ source. On Day 0 and Day 2 after reconstitution, the recipient mice were injected i.p. with $100 \mu \mathrm{g}$ of anti-NK1.1 antibody for $\mathrm{H}-2^{\mathrm{d} \times \mathrm{b}}$ chimeras or anti-NK 5E6 for $\mathrm{H}-2^{\mathrm{d} \times \mathrm{k}}$ chimeras to deplete residual host NK cells that have been shown to mediate Hh barrier rejection of BM (15). The extent of chimerism in each mouse was confirmed by staining peripheral blood cells and spleen cells with FITC-labeled anti-H-2 ${ }^{\mathrm{b}}$ and PElabeled anti- $\mathrm{H}-2^{\mathrm{d}}$ antibodies. All antibodies were purchased from PharMingen.

\section{Immunization and Transplantation Protocol}

The chimera mice were immunized with i.m. injections of $100 \mu \mathrm{g}$ of VIJnsNP plasmid DNA at Week 0 and Week 2, or with intranasal infection with a sublethal dose of influenza virus $A / P R /$ $8 / 34$ at Week 0 . At Week 4, spleen cells were harvested and restimulated in vitro with irradiated (40 Gy) Fl spleen cells either pulsed with indicated peptide or infected with influenza virus A/PR/8/34. After 7 days of culture at $37^{\circ} \mathrm{C}(5 \%$ $\mathrm{CO}_{2}$ ) in RPMI 1640 medium with $10 \%$ fetal calf serum (FCS), the cells were harvested and tested for CTL activity using 3-fold serial dilutions in a 4-hr chromium release assay.

C2C12 $\left(H-2^{k}\right)$ cells were obtained from ATCC (Rockville, $\mathrm{MD}$ ) and maintained in high-glucose Dulbeco's Modified Eagle Medium (DMEM) supplemented with $10 \%$ fetal bovine serum (FBS) (Hyclone Labs, Inc., Logan, Utah), penicillin, streptomycin, and glutamine. Stable transfectants expressing influenza NP (A/PR/8/34) were prepared as previously described (4). Transfected cells were implanted by i.m. injection into the quadriceps muscles. A total of $1 \times 10^{7}$ cells in $100 \mu \mathrm{l}$ were injected in a total of 5 sites per quadriceps.

\section{Cells and CTL Cultures}

P815 $\left(H-2^{d}\right)$, L929 $\left(H-2^{k}\right)$ and EL4 $\left(H-2^{b}\right)$ cells, routinely used as target cells for the cytotoxicity assay, were maintained in DMEM supplemented with $10 \%$ heat-inactivated fetal bovine serum (FBS), $2 \mathrm{mM}$ L-glutamine, $100 \mathrm{U} / \mathrm{ml}$ penicillin, 100 $\mu \mathrm{g} / \mathrm{ml}$ streptomycin, $5 \mathrm{mM}$ HEPES ( $N$-2-hydroxyethylpiperazine- $N^{\prime}$-2-ethanesulfonic acid) and $0.0225 \%$ sodium bicarbonate. All cell culture re- agents were purchased from GIBCO/BRL Life Technologies (Grand Island, NY).

Spleen cells were cultured to generate effector CTL as previously described $(3,5)$. Spleen cell cultures were maintained in RPMI 1640 media supplemented with $10 \%$ FBS, $2 \mathrm{mM}$ L-glutamine, $5 \times 10^{-5} \mathrm{M} \beta$-mercaptoethanol, 25 $\mu \mathrm{g} / \mathrm{ml}$ pyruvic acid, $100 \mathrm{U} / \mathrm{ml}$ penicillin, 100 $\mu \mathrm{g} / \mathrm{ml}$ streptomycin, $5 \mathrm{mM}$ HEPES and $0.0225 \%$ sodium bicarbonate. Irradiated syngeneic cells, either pulsed with peptide (5-10 $\mu \mathrm{M})$ or infected with $\mathrm{A} / \mathrm{PR} / 8 / 34$ virus, were used as stimulator cells. Unless specified, no IL-2 was added in the first round of in vitro restimulation. Long-term CTL cultures were maintained in complete RPMI 1640 media plus $10 \mathrm{U} / \mathrm{ml}$ recombinant human IL-2.

\section{Cytotoxicity Assay}

The cytotoxicity assays were performed as described previously $(3,5)$. Briefly, target cells labeled with $\mathrm{Na}^{51} \mathrm{CrO}_{4}$ (Amersham Life Sciences, Arlington Heights, IL) were either infected with influenza virus A/Victoria/73 (H3N2), or pulsed with synthetic peptides at 5 - to $10-\mu \mathrm{M}$ concentration. The target cells were then mixed with CTL at designated effector:target cell ratios in 96-well plates, and incubated at $37^{\circ} \mathrm{C}$ for $4 \mathrm{hr}$ in the presence of $5 \% \mathrm{CO}_{2}$. A $20-\mu \mathrm{l}$ sample of supernatant from each cell mixture was counted to determine the amount of ${ }^{51} \mathrm{Cr}$ released from target cells. The percentage of specific lysis was calculated using the formula below:

$$
\% \text { specific lysis }=(E-S) /(M-S)
$$

where $E$ represents the average cpm released from target cells in the presence of effector cells, $S$ is the spontaneous cpm released in the presence of media only, and $M$ is the maximum cpm released in the presence of $5 \%$ SDS or $2 \%$ Triton $\mathrm{X}-100$.

\section{RESULTS}

\section{Bone Marrow Chimeric Mice}

Three CTL epitopes of influenza NP restricted by $H-2 K^{d}, H-2 D^{b}$, and $H-2 K^{k}$ molecules, respectively, are shown in Fig. 1A, and the concept of an F1 BM chimera is depicted in Fig. 1B. Briefly, lethally irradiated $\mathrm{Fl}$ mice of two strains represented as " $A$ " and " $B$ " receive BM cells derived from one parental strain. The hematopoietic lin- 
$\mathbf{A}$

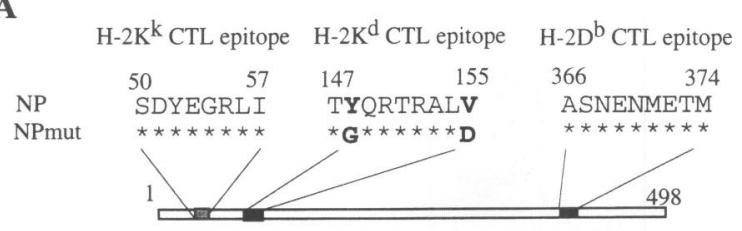

B

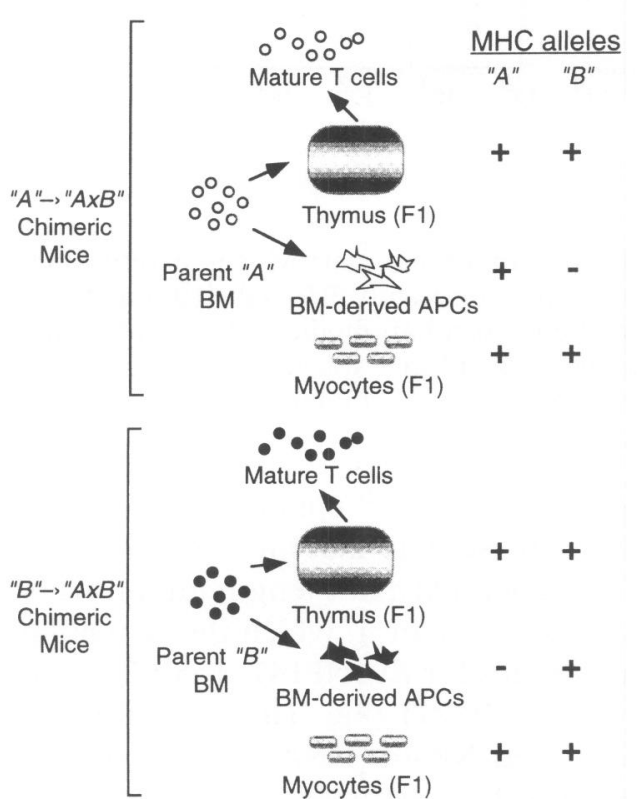

FIG. 1. Schematic drawing showing locations of CTL epitopes within the NP open reading frame (A) and the concept of $B M$ chimeric mice (B)

Amino acid sequences are expressed in single-letter code. BM-derived APCs are expected to express only the haplotype of their BM donor and thus present peptides in the context of the BM donor MHC allele rather than both alleles, whereas the myocytes (and other somatic cells) in the chimeras are expected to express both MHC alleles; thus, if they prime CTL responses in vivo, they would present peptides restricted by both haplotypes. Since the thymic epithelial cells express both parental MHC alleles, the T cell receptor repertoires are expected to include receptors that recognize peptides in the context of both parental haplotypes, even though the $\mathrm{T}$ cells themselves only express the BM donor's haplotype.

eage cells in these chimeras, including professional APCs, such as macrophages and dendritic cells (DCs), should express only the donor haplotype, whereas the somatic cells, such as myocytes and respiratory epithelial cells, should express both parental strain MHC alleles.

Initially two sets of parent $\rightarrow$ Fl BM chimeras, $\mathrm{BALB} / \mathrm{C}\left(\mathrm{H}-2^{\mathrm{d}}\right) \rightarrow(\mathrm{BALB} / \mathrm{C} \times \mathrm{C} 57 \mathrm{BL} / 6) \mathrm{Fl}$ $\left(\mathrm{H}-2^{\mathrm{d} \times \mathrm{b}}\right)$, and $\mathrm{C} 57 \mathrm{BL} / 6\left(\mathrm{H}-2^{\mathrm{b}}\right) \rightarrow \mathrm{F} 1\left(\mathrm{H}-2^{\mathrm{d} \times \mathrm{b}}\right)$, were generated. $\mathrm{Fl} \rightarrow \mathrm{Fl}$ chimeras were gener- ated as controls. Staining of peripheral blood lymphocytes from the chimeras with $\mathrm{MHC}$ allele-specific antibodies confirmed that their lymphoid cells were derived from the corresponding donor BM cells (Fig. 2). Since thymic stromal epithelial cells in all chimeras expressed both $\mathrm{H}-2^{\mathrm{d}}$ and $\mathrm{H}-2^{\mathrm{b}}$ alleles, the $\mathrm{T}$ cells in these mice were expected to be selected during their thymic education to recognize antigens in the context of either haplotype (16-18). Previously, Huang et al. $(13,19)$ demonstrated that $\mathrm{H}-2^{\mathrm{b}} \rightarrow \mathrm{H}-2^{\mathrm{d} \times \mathrm{b}}$ chimeras, when immunized with live $\mathrm{DBA} / 2$ mouse splenocytes, could mount $\mathrm{H}-2^{\mathrm{d}}$-restricted CTL responses against $\mathrm{DBA} / 2$ minor histocompatibility antigen, indicating that $\mathrm{T}$ cells that were specific for antigenic peptides in the context of both $\mathrm{H}-2^{\mathrm{d}}$ and $\mathrm{H}-2^{\mathrm{b}}$ alleles were appropriately selected in the $\mathrm{H}-2^{\mathrm{b}} \rightarrow \mathrm{H}-2^{\mathrm{d} \times \mathrm{b}}$ chimeras. To control for the ability of our chimeras to develop appropriate $\mathrm{T}$ cell receptor repertoires, we likewise demonstrated this finding in these mice (results not shown), thus indicating that they were capable of mounting a CTL response to minor $\mathrm{H}$ epitopes in the context of the $\mathrm{H}-2^{\mathrm{d}}$ allele, and therefore would be capable of mounting CTL responses to peptides from foreign proteins restricted by the $\mathrm{H}-2^{\mathrm{d}}$ MHC molecules.

\section{For Virus Infection or DNA Vaccines, Priming CTL Requires BM-derived APCs}

To validate the ability of chimeras to mount NPspecific CTL responses, chimeric mice were intranasally infected with a sublethal dose of live influenza virus. Their splenic lymphocytes were restimulated in vitro with $\mathrm{Fl}$ spleen cells pulsed with either $\mathrm{H}-2 \mathrm{D}^{\mathrm{b}}$ peptide NP366 -374 or $\mathrm{H}-2 \mathrm{~K}^{\mathrm{d}}$ peptide NP147-155 for 7 days. EL4 cells $\left(\mathrm{H}-2^{\mathrm{b}}\right)$ pulsed with the $\mathrm{H}-2 \mathrm{D}^{\mathrm{b}}$ peptide $\left(\mathrm{H}-2 \mathrm{D}^{\mathrm{b}}\right.$ target) and P815 cells $\left(\mathrm{H}-2^{\mathrm{d}}\right)$ pulsed with the $\mathrm{H}-2 \mathrm{~K}^{\mathrm{d}}$ peptide $\left(\mathrm{H}-2 \mathrm{~K}^{\mathrm{d}}\right.$ target) were used as target cells to assess the lytic activities of these chimeric splenocytes in a standard cytotoxicity assay. As shown in Fig. 3A, splenocytes from the $\mathrm{H}-2^{\mathrm{b}} \rightarrow$ $\mathrm{H}-2^{\mathrm{d} \times \mathrm{b}}$ chimeras, after restimulation with $\mathrm{Fl}$ spleen cells pulsed with the $H-2 D^{b}$ peptide, lysed only the $\mathrm{H}-2 \mathrm{D}^{\mathrm{b}}$ target and did not lyse the $\mathrm{H}-2 \mathrm{~K}^{\mathrm{d}}$ target after restimulation with $\mathrm{Fl}$ cells pulsed with $\mathrm{H}-2 \mathrm{~K}^{\mathrm{d}}$ peptide. Conversely, splenocytes from the $\mathrm{H}-2^{\mathrm{d}} \rightarrow \mathrm{H}-2^{\mathrm{d} \times \mathrm{b}}$ chimeras, when restimulated with Fl splenocytes pulsed with the $H-2 K^{d}$ peptide, specifically recognized the $H-2 K^{d}$ target but did not lyse the $\mathrm{H}-2 \mathrm{D}^{\mathrm{b}}$ target after restimulation with the $\mathrm{Fl}$ splenocytes pulsed with $H-2 D^{b}$ peptide. Thus, our chimeras infected intra- 

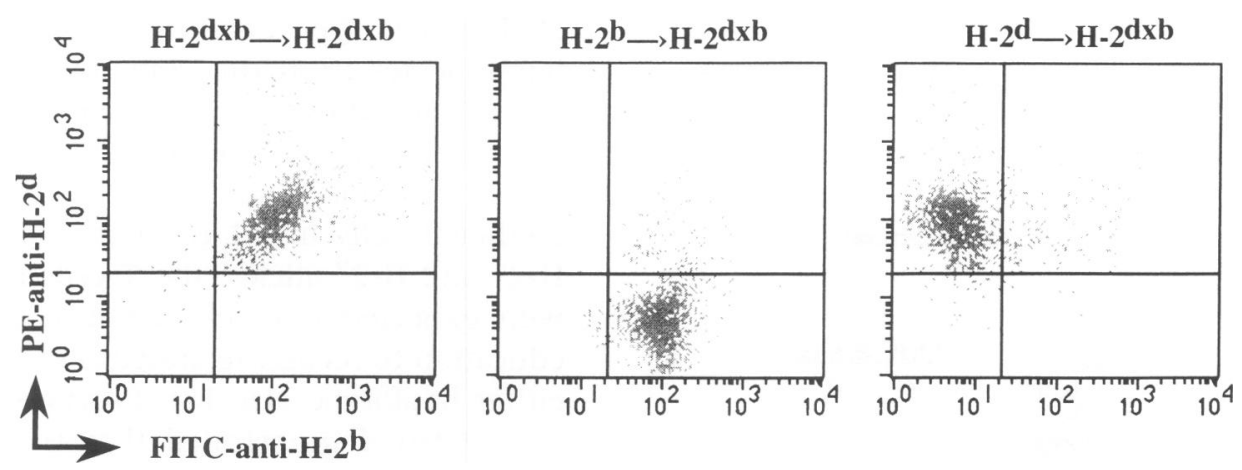

FIG. 2. Flow cytometry analysis of chimeric mice

Approximately 2 months after reconstitution of irradiated Fl mice with parental bone marrow, the extent of chimerism was confirmed by staining peripheral blood lymphocytes from each mouse with FITC-labeled anti- $\mathrm{H}-2^{\mathbf{b}}$ and PE-labeled anti-H- $2^{\mathrm{d}}$ antibodies (Pharmingen) or with isotype-matched control antibodies. Mice containing less than $4 \%$ residual host lymphocytes were used for studies. Prior to in vitro culture, spleen cells were stained as above to confirm chimerism. Representative dot plots corresponding to the three types of chimeric mice are shown.

nasally with live influenza virus could mount NPspecific CTL responses, and the CTL responses were restricted to the haplotype of donor BM cells. This finding further indicates that, even though the $\mathrm{H}-2^{\mathrm{d} \times \mathrm{b}}$ respiratory epithelial cells expressing both haplotypes are infected by influenza virus, they are not direct antigen-presenting cells for priming NPspecific CTL responses.

Lymphocytes isolated from chimeras injected i.m. with NP DNA were restimulated and tested under the same conditions as those above (Fig. 3B). After i.m. NP DNA immunization, splenocytes from the $\mathrm{H}-2^{\mathrm{d} \times \mathrm{b}} \rightarrow \mathrm{H}-2^{\mathrm{d} \times \mathrm{b}}(\mathrm{Fl} \rightarrow$ F1) control chimeras lysed both EL4 cells $\left(\mathrm{H}-2^{\mathrm{b}}\right)$ pulsed with the $\mathrm{H}-2 \mathrm{D}^{\mathrm{b}}$ peptide $\left(\mathrm{H}-2 \mathrm{D}^{\mathrm{b}}\right.$ target) and $\mathrm{P} 815$ cells $\left(\mathrm{H}-2^{\mathrm{d}}\right)$ pulsed with the $\mathrm{H}-2 \mathrm{~K}^{\mathrm{d}}$ peptide $\left(\mathrm{H}-2 \mathrm{~K}^{\mathrm{d}}\right.$ target $)$ after corresponding epitope peptide restimulation (Fig. 3B). Splenocytes from the $\mathrm{H}-2^{\mathrm{b}} \rightarrow \mathrm{H}-2^{\mathrm{d} \times \mathrm{b}}$ chimeras immunized with NP DNA, after restimulation with F1 spleen cells pulsed with the $\mathrm{H}-2 \mathrm{D}^{\mathrm{b}}$ peptide, recognized only the $\mathrm{H}-2 \mathrm{D}^{\mathrm{b}}$ target and did not lyse the $\mathrm{H}-2 \mathrm{~K}^{\mathrm{d}}$ target after restimulation with $\mathrm{H}-2 \mathrm{~K}^{\mathrm{d}}$ peptide. Likewise, lymphocytes from the $\mathrm{H}-2^{\mathrm{d}} \rightarrow$ $\mathrm{H}-\mathrm{2}^{\mathrm{d} \times \mathrm{b}}$ chimeras immunized with NP DNA, when restimulated with $\mathrm{Fl}$ splenocytes pulsed with the $\mathrm{H}-2 \mathrm{~K}^{\mathrm{d}}$ peptide, specifically lysed the $\mathrm{H}-2 \mathrm{~K}^{\mathrm{d}}$ target but did not recognize the $\mathrm{H}-2 \mathrm{D}^{\mathrm{b}}$ target after restimulation with the $\mathrm{H}-2 \mathrm{D}^{\mathrm{b}}$ peptide. Therefore, NP DNA immunization induced an MHC allele-specific CTL response restricted to the haplotype of the donor BM cells.

To control for the possibility that the lack of the $\mathrm{H}-2 \mathrm{D}^{\mathrm{b}}$-restricted response in NP DNA-immunized $\mathrm{H}-2^{\mathrm{d}} \rightarrow \mathrm{H}-2^{\mathrm{d} \times \mathrm{b}}$ chimeras was a result of antigenic competition between the $\mathrm{H}-2 \mathrm{~K}^{\mathrm{d}}$ epitope and the $\mathrm{H}-2 \mathrm{D}^{\mathrm{b}}$ epitope in antigen processing and presentation at intra- or intercellular levels, we generated a full-length mutant version of the NP DNA vector in which the two putative anchor residues for the NP147-155 CTL epitope were altered $(20,21)$ (Fig. 1B). This mutant NP vector, termed NPmut DNA, though unable to induce the $\mathrm{H}-2 \mathrm{~K}^{\mathrm{d}}$-restricted 147-155-specific response in BALB/C mice, was capable of inducing an $\mathrm{H}-2 \mathrm{D}^{\mathrm{b}}$-restricted $366-374$-specific response in C57BL/6 mice (5). Upon immunization with NPmut DNA, the H-2K ${ }^{\mathrm{d}}$-restricted 147-155-specific response was not detectable in either $\mathrm{H}-2^{\mathrm{d}}$ $\rightarrow \mathrm{H}-2^{\mathrm{d} \times \mathrm{b}}$ or $\mathrm{H}-2^{\mathrm{d} \times \mathrm{b}} \rightarrow \mathrm{H}-2^{\mathrm{d} \times \mathrm{b}}$ chimeras, whereas the $\mathrm{H}-2 \mathrm{D}^{\mathrm{b}}$-restricted $366-374$-specific response was observed in both $\mathrm{H}-2^{\mathrm{b}} \rightarrow \mathrm{H}-2^{\mathrm{d} \times \mathrm{b}}$ and $\mathrm{H}-2^{\mathrm{d} \times \mathrm{b}} \rightarrow \mathrm{H}-2^{\mathrm{d} \times \mathrm{b}}$ mice (Fig. 4,A and $\mathrm{B}$ ). However, no CTL response could be detected against the $\mathrm{H}-2 \mathrm{D}^{\mathrm{b}}$ peptide in $\mathrm{H}-2^{\mathrm{d}} \rightarrow \mathrm{H}-2^{\mathrm{d} \times \mathrm{b}}$ chimeras even when mice were immunized with NPmut DNA in which the functional presentation of the $\mathrm{H}-2 \mathrm{~K}^{\mathrm{d}}$-restricted $147-155$ epitope was absent. Thus, the lack of the $\mathrm{H}-2 \mathrm{D}^{\mathrm{b}}$-restricted CTL response in $\mathrm{H}-2^{\mathrm{d}} \rightarrow \mathrm{H}-2^{\mathrm{d} \times \mathrm{b}}$ chimeras could not be attributed to immunodominance of the $\mathrm{H}-2 \mathrm{~K}^{\mathrm{d}}$-restricted NP147-155 epitope, indicating that presentation following NP DNA immunization was indeed restricted to the haplotype of the BM donor cells and, hence, the APCs were BMderived cells rather than myocytes.

\section{Transfer of Antigen from Myocytes to APCs}

To further investigate the role of myocytes after DNA immunization by the i.m. route, a different 


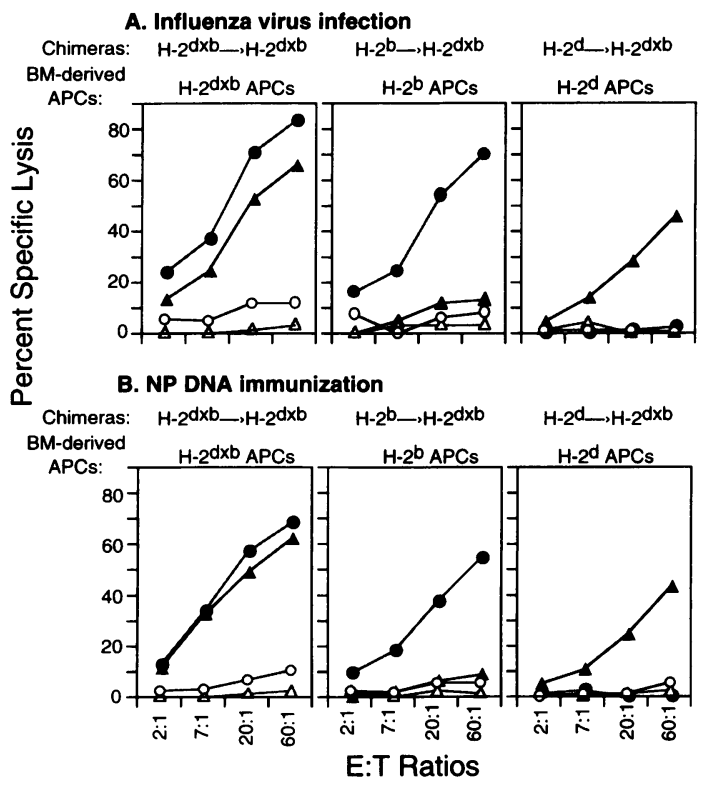

FIG. 3. NP-specific CTL responses induced by live influenza infection (A) or NP DNA immunization (B) are restricted by the MHC haplotype of the BM APCs in chimeras

Spleen cells from chimeric mice immunized by intranasal infection with live influenza virus or by i.m. injection with NP DNA were restimulated in vitro for 7 days with Fl spleen cells pulsed with either $\mathrm{H}-2 \mathrm{D}^{\mathrm{b}}$-restricted peptide NP366-374 or H-2K ${ }^{\mathrm{d}}$-restricted peptide NP147-155. The resulting effector cells were tested against EL4 $\left(\mathrm{H}-2^{\mathrm{b}}\right)$ cells pulsed with the $\mathrm{H}-2 \mathrm{D}^{\mathrm{b}}$ peptide or P815 $\left(\mathrm{H}-2^{\mathrm{d}}\right)$ cells pulsed with the $\mathrm{H}-2 \mathrm{~K}^{\mathrm{d}}$ peptide. Open circles represent the lysis of P815 cells pulsed with $\mathrm{H}-2 \mathrm{~K}^{\mathrm{d}}$ peptide by the spleen cells restimulated with $\mathrm{H}-2 \mathrm{D}^{\mathrm{b}}$ peptide (allele-mismatched restimulation) and closed circles represent the lysis of $\mathrm{P} 815$ cells pulsed with $\mathrm{H}-2 \mathrm{~K}^{\mathrm{d}}$ peptide by the spleen cells restimulated with $\mathrm{H}-2 \mathrm{~K}^{\mathrm{d}}$ peptide (allele-matched restimulation). Open triangles represent the lysis of EL4 cells pulsed with $\mathrm{H}-2 \mathrm{D}^{\mathrm{b}}$ peptide by the spleen cells restimulated with $\mathrm{H}-2 \mathrm{~K}^{\mathrm{d}}$ peptide (allele-mismatched restimulation) and closed triangles represent the lysis of EL4 cells pulsed with $\mathrm{H}-2 \mathrm{D}^{\mathrm{b}}$ peptide by the spleen cells restimulated with $\mathrm{H}-2 \mathrm{D}^{\mathrm{b}}$ peptide (allele-matched restimulation). The data shown are representative of three independent experiments. The percent lysis by spleen cells from mock-immunized and mock-infected control mice was less than $15 \%$, and the percent lysis of the nonspecific control targets (P815 cells pulsed with $\mathrm{H}-2 \mathrm{D}^{\mathrm{b}}$-restricted NP366-374 peptide or EL4 cells pulsed with $\mathrm{H}-2 \mathrm{~K}^{\mathrm{d}}$-restricted NP147-155 peptide) ranged from $7 \%$ at an E:T ratio of $2: 1$ to $15.6 \%$ at an E:T ratio of 60:1 (results not shown).

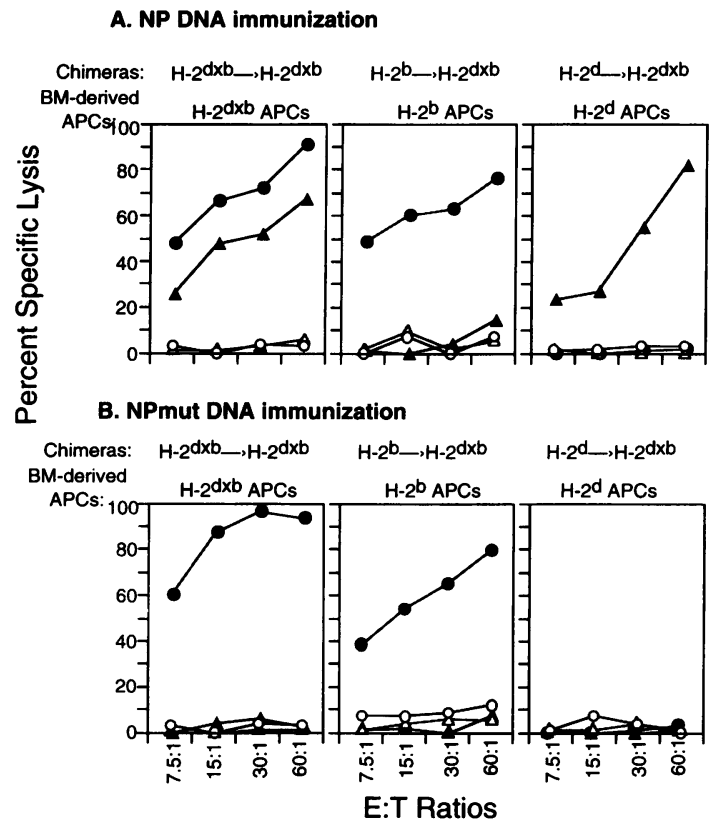

FIG. 4. Lack of antigen competition from immunodominant H-2K $\mathrm{K}^{\mathrm{d}}$-restricted 147-155 epitope-specific CTL response does not result in generation of $H-2 D^{b}$-restricted CTL responses in $\mathbf{H}-2^{d} \rightarrow \mathbf{H}-2^{d \times b}$ chimeras.

Spleen cells from chimeras immunized with NP DNA (A) or NPmut DNA (B) were in vitro restimulated with $\mathrm{Fl}$ spleen cells pulsed with $\mathrm{H}-2 \mathrm{D}^{\mathrm{b}}$ peptide NP366-374 or H-2 $\mathrm{K}^{\mathrm{d}}$ peptide NP147-155 for 7 days, and used as effector cells against EL4 cells pulsed with $\mathrm{H}-2 \mathrm{D}^{\mathrm{b}}$ peptide NP366-374 or P815 cells pulsed with $\mathrm{H}-2 \mathrm{~K}^{\mathrm{d}}$ peptide NP147-155 in a cytotoxicity assay. Open circles represent the lysis of P815 cells pulsed with $\mathrm{H}-2 \mathrm{~K}^{\mathrm{d}}$ peptide by the spleen cells restimulated with $\mathrm{H}-2 \mathrm{D}^{\mathrm{b}}$ peptide (allele-mismatched restimulation) and closed circles represent the lysis of P815 cells pulsed with $\mathrm{H}-2 \mathrm{~K}^{\mathrm{d}}$ peptide by the spleen cells restimulated with $\mathrm{H}-2 \mathrm{~K}^{\mathrm{d}}$ peptide (allelematched restimulation). Open triangles represent the lysis of EL4 cells pulsed with $\mathrm{H}-2 \mathrm{D}^{\mathrm{b}}$ peptide by the spleen cells restimulated with $\mathrm{H}-2 \mathrm{~K}^{\mathrm{d}}$ peptide (allelemismatched restimulation) and closed triangles represent the lysis of EL4 cells pulsed with $\mathrm{H}-2 \mathrm{D}^{\mathrm{b}}$ peptide by the spleen cells restimulated with $H-2 D^{b}$ peptide (allele-matched restimulation). The data shown are representative of two independent experiments. The percent lysis by the spleen cells from mock-immunized control mice, and the percent lysis of the nonspecific control targets (P815 cells pulsed with NP366-374 peptide or EL4 cells pulsed with $147-155$ peptide) ranged from $3 \%$ at an E:T ratio of 7.1:1 to $20 \%$ at an E:T ratio of $60: 1$ (results not shown). The NPmut construct encodes a full-length NP protein containing a tyrosine-to-glycine change at residue 148 and a valine-to-aspartic acid change at 155 (putative anchor positions, see Fig. 1A for details). 


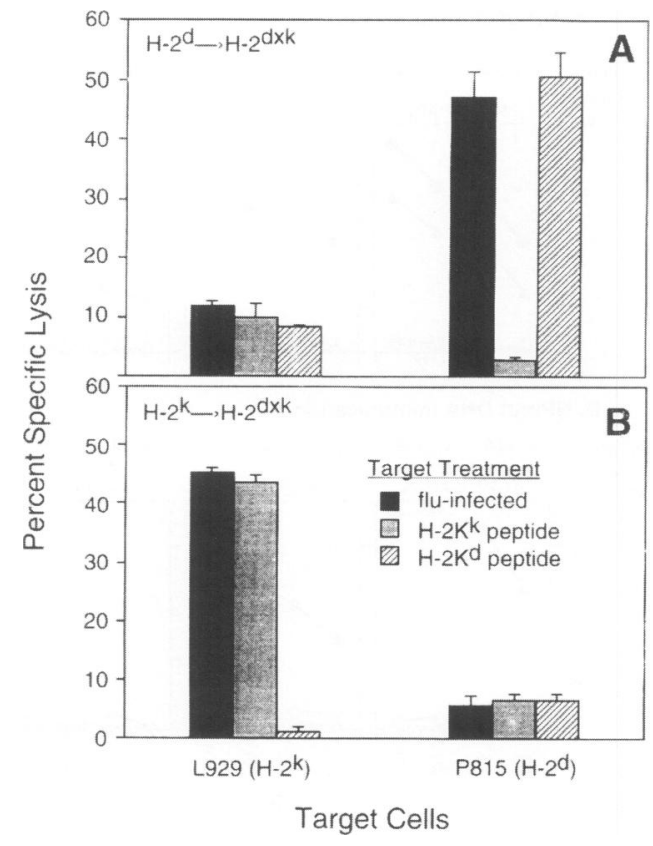

FIG. 5. NP-specific CTL responses induced by i.m. NP DNA immunization are restricted by the BM MHC haplotype in ${\mathrm{H}-2^{\mathrm{d} \times \mathrm{k}}}_{\mathrm{BM}}$ chimeric mice

$\mathrm{H}-2^{\mathrm{d}} \rightarrow \mathrm{H}-2^{\mathrm{d} \times \mathrm{k}}(\mathrm{A})$ and $\mathrm{H}-2^{\mathrm{k}} \rightarrow \mathrm{H}-2^{\mathrm{d} \times \mathrm{k}}$ (B) chimeras were injected i.m. with NP DNA $(100 \mu \mathrm{g})$ on Weeks 0,3 , and 6 and spleen cells were prepared on Week 8. Cells were restimulated with Fl spleen cells infected with A/PR/8/34 influenza virus for 7 days. P815 $\left(\mathrm{H}-2^{\mathrm{d}}\right)$ and $\mathrm{L} 929\left(\mathrm{H}-2^{\mathrm{k}}\right)$ target cells were infected with influenza A/Victoria/73 virus (solid bars), or pulsed with the $\mathrm{H}-2 \mathrm{~K}^{\mathrm{k}}$ peptide NP 50-57 (shaded bars) or $\mathrm{H}-2 \mathrm{~K}^{\mathrm{d}}$ peptide NP 147-155 (striped bars) and incubated with CTL at an E:T ratio of 50:1. Data are plotted as percent specific lysis \pm SD, where $n=3$.

set of F1 BM chimeras (between DBA/2 $\left(\mathrm{H}-2^{\mathrm{d}}\right)$ and $\mathrm{C} 3 \mathrm{H}\left(\mathrm{H}-2^{\mathrm{k}}\right)$ mice) was generated. I.m. injection of NP DNA induced CTL responses in a pattern analogous to that found in $\mathrm{BALB} / \mathrm{c} \times$ C57BL/6 BM chimeras (Fig. 5): the CTL response specific to the H-2K ${ }^{\mathrm{d}}$-restricted epitope NP147155 was seen only in $\mathrm{H}-2^{\mathrm{d}} \rightarrow \mathrm{H}-2^{\mathrm{d} \times \mathrm{k}}$ chimeras (panel A), and only the CTL response specific to the $\mathrm{H}-2 \mathrm{~K}^{\mathrm{k}}$-restricted epitope NP50-57 was demonstrated in $\mathrm{H}-2^{\mathrm{k}} \rightarrow \mathrm{H}-2^{\mathrm{d} \times \mathrm{k}}$ chimeras (panel B). These results provided further evidence that $\mathrm{BM}$ derived cells rather than muscle cells were primary APCs for induction of CTL. Transplantation of an $\mathrm{H}-2^{\mathrm{k}}$ haplotype myoblast cell line $(\mathrm{C} 2 \mathrm{C} 12)$ that had been stably transfected with the NP gene (4) into $\mathrm{H}-2^{\mathrm{d}} \rightarrow \mathrm{H}-2^{\mathrm{d} \times \mathrm{k}}$ chimeras induced a CTL response specifically directed against the $\mathrm{H}-2 \mathrm{~K}^{\mathrm{d}}$-restricted epitope upon restimulation of

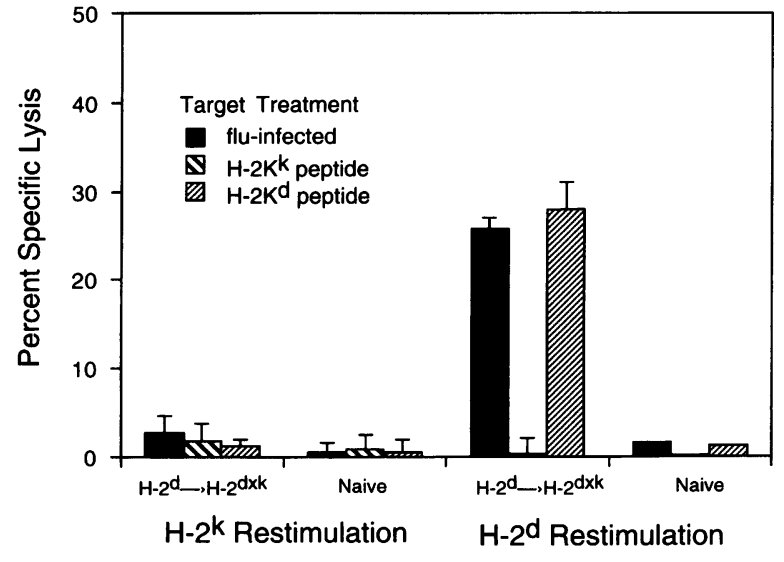

FIG. 6. Induction of CTL in $H-2^{d \times k} B M$ chimeric mice after transplantation of NP-expressing myoblasts

$\mathrm{H}-2^{\mathrm{d}} \rightarrow \mathrm{H}-2^{\mathrm{d} \times \mathrm{k}}$ mice were injected i.m. with NPexpressing myoblasts and spleen cells were prepared 6 weeks after transplantation. Cells were restimulated with $\mathrm{F} 1$ spleen cells pulsed with $\mathrm{H}-2 \mathrm{~K}^{\mathrm{k}}$ peptide NP 50-57 or H-2K $\mathrm{K}^{\mathrm{d}}$ peptide NP 147-155 for 7 days. P815 $\left(\mathrm{H}-2^{\mathrm{d}}\right)$ and L929 $\left(\mathrm{H}-2^{\mathrm{k}}\right)$ target cells were infected with influenza A/Victoria/73 virus (solid bars), or pulsed with the $\mathrm{H}-2 \mathrm{~K}^{\mathrm{k}}$ (shaded bars) or $\mathrm{H}-2 \mathrm{~K}^{\mathrm{d}}$ (striped bars) peptides and incubated with CTL at an E:T ratio of 50:1. Data are plotted as percent specific lysis $\pm \mathrm{SD}$, where $n=3$. Similar results were seen when restimulation was performed by using influenza virus-infected Fl spleen cells as stimulators (results not shown).

the splenocytes with Fl cells either infected with influenza virus or pulsed with $\mathrm{H}-2 \mathrm{~K}^{\mathrm{d}}$ peptide in vitro, whereas the CTL response against the $\mathrm{H}-2 \mathrm{~K}^{\mathrm{k}}$-restricted epitope NP50-57 could not be detected even after in vitro restimulation with $\mathrm{F} 1$ spleen cells infected with influenza virus or pulsed with $\mathrm{H}-2 \mathrm{~K}^{\mathrm{k}}$ peptide (Fig. 6). These results indicated that NP synthesis in muscle cells was sufficient for induction of CTL responses, even though the transplanted myoblasts or myocytes to which they may have fused did not function as direct APC for priming the CTL responses. These data demonstrate that myocytes can provide an antigen source for the induction of MHC class I-restricted CTL responses by BM-derived APCs. Thus, direct transfection of APCs by the DNA is not required for the induction of CTL.

\section{DISCUSSION}

Using two different types of radiation parent $\rightarrow$ F1 BM chimeric mice, we demonstrated that in vivo priming of MHC class I-restricted CTL re- 
sponses by injection of NP DNA and transplantation of NP-expressing myoblast cells required presentation by MHC allotype-matched professional APCs. In essence, the CTL response against NP peptides could not be generated unless the peptides were presented in the context of MHC molecules present on BM-derived professional APCs. Since one of the critical observations upon which the conclusions are based is the absence of the specific CTL response restricted by the nondonor MHC haplotype, it is essential to validate the BM chimera model from two perspectives. First, antigenic competition between NP peptides presented by the various MHC haplotypes did not mask the response to one of the epitopes. Second, an appropriate repertoire of $\mathrm{T}$ cell receptors (TCRs) exists on mature $\mathrm{T}$ cells that includes receptors capable of recognizing peptides in the context of either parental MHC haplotype. In this study, the former was demonstrated utilizing a mutant NP DNA construct that selectively abolished recognition of an $\mathrm{H}-2 \mathrm{~K}^{\mathrm{d}}$-restricted dominant epitope (Fig. 4B), and the latter by immunization with DBA/ 2 spleen cells to confirm the integrity of the $\mathrm{T}$ cell repertoire in the chimeras (results not shown).

Although myocytes synthesize proteins after DNA injection (8) and more specifically, NP after NP DNA injection (J. B. Ulmer, M. Cartwright et al., unpublished observations), the present study documented that myocytes were not direct antigen-presenting cells for priming CTL responses; rather, BM-derived APCs were responsible for presenting NP peptides in the context of MHC class I molecules to prime naive $T$ cells. It was possible that these BM-derived APCs either were directly transfected by injected NP DNA or acquired NP antigen from transfected myocytes. In an analogous situation, priming of CTL responses in influenza virus-infected chimeras, shown to be restricted to the haplotype of the BM APCs, may result from direct infection of $B M$-derived APCs or transfer of antigen from influenza virusinfected epithelial cells to BM-derived APCs (Fig. 3A).

Previous studies from our laboratory showed that i.m. or i.p. transplantation of viable myoblasts stably transfected with the NP gene was sufficient to induce CTL responses. Intraperitoneal (i.p.) transplantation of NP DNA-transfected myoblasts of the $\mathrm{H}-2^{\mathrm{k}}$ haplotype was able to prime both $\mathrm{H}-2^{\mathrm{d}}$ - and $\mathrm{H}-2^{\mathrm{k}}$-restricted CTL responses in DBA $/ 2 \times \mathrm{C} 3 \mathrm{H} \mathrm{Fl}\left(\mathrm{H}-2^{\mathrm{d} \times \mathrm{k}}\right)$ mice (4). In these transplantation experiments, no plasmid DNA was available in vivo to transfect non- muscle cells, since the NP gene was stably integrated into the myoblasts' genome in cell culture. Therefore, expression of NP in BM-derived APCs was not necessary for generating CTL responses, and the results from i.p. transplantation studies indicated that antigen transfer from transplanted myoblasts to host APCs for priming CTL responses can occur. However, since in the latter study the myoblasts were transplanted intraperitoneally to eliminate fusion between implanted myoblasts $\left(\mathrm{H}-2^{\mathrm{k}}\right)$ and host striated muscle cells $\left(\mathrm{H}-2^{\mathrm{d} \times \mathrm{k}}\right)$, the antigen transfer as a means to generate CTL responses in this case was of unknown relevance to myocytes in situ following direct transfection by i.m. DNA injection.

In the present study, we administered NP DNA-transfected $\mathrm{H}-2^{\mathrm{k}}$ myoblasts by i.m. transplantation into $\mathrm{H}-2^{\mathrm{d}} \rightarrow \mathrm{H}-2^{\mathrm{d} \times \mathrm{k}}$ BM chimera mice. An $\mathrm{H}-2 \mathrm{~K}^{\mathrm{d}}$-restricted CTL response but not an $\mathrm{H}-2 \mathrm{~K}^{\mathrm{k}}$-restricted CTL response was observed, clearly indicating that the transplanted muscle cells were not APCs for priming such a CTL response (Fig. 6), even though the fusion of the transplanted cells with host myocytes leading to expression of NP in these cells may occur (22). Induction of CTL by NP produced in muscle cells in situ after i.m. DNA injection (vide supra) likewise required BM-derived APCs. As with i.m. injection of DNA, only the CTL response restricted by the MHC haplotype of donor BM cells was demonstrated after restimulation of splenocytes from these mice (Figs. 3-5), although in the transplantation studies direct transfection of BMderived cells clearly could not be involved. These findings support the hypothesis that myocytes can provide an antigen source for the induction of MHC class I-restricted CTL responses, i.e., that antigen can be synthesized in myocytes, but following transfer to professional APCs, is presented by these BM-derived APCs to prime CTL responses. Although BM-derived APCs following i.m. injection of DNA might be transfected and participate in induction of CTL responses, our observations, including the finding that the i.m. route of DNA immunization is superior for inducing CTL responses (1), are consistent with an antigen transfer process from antigen-producing cells (myocytes) to professional APCs for the induction of MHC class I-restricted CTL responses.

BM-derived APCs express high levels of MHC class I and II molecules, as well as adhesion/costimulatory molecules, and their potency in initiating $\mathrm{T}$ cell responses has been demonstrated in several systems $(23,24)$. Recent reports have shown that professional APCs can present 
antigen for induction of MHC class I-restricted CTL responses following i.m. or intradermal immunization with DNA vaccines, but the APCs were not shown to be required for priming the CTL $(25,26)$ and the potential role of other cells, such as the myocytes, was not addressed (2527). However, this study demonstrates definitively that professional antigen-presenting cells, i.e., BM-derived APCs, are required for CTL priming. We have supported this observation by demonstrating that the $\mathrm{H}-2^{\mathrm{b}} \rightarrow \mathrm{H}-2^{\mathrm{d} \times \mathrm{b}}$ BM chimeras used in our studies possessed a $\mathrm{T}$ cell receptor repertoire capable of responding to antigens in the context of either parental MHC haplotype. In addition, we ruled out the possibility of antigenic competition between the dominant CTL epitopes of the $\mathrm{H}-2^{\mathrm{d}}$ and $\mathrm{H}-2^{\mathrm{b}}$ haplotypes. Both of these controls are essential for validation of the system and necessary for proving that APCs are required. Furthermore, our study demonstrated that it is not necessary for professional APCs to be transfected by injected DNA in order for the induction of CTL to occur, since we showed that antigen synthesized in situ by myocytes was presented by professional APCs for induction of MHC class I-restricted CTL responses. Finally, we also showed that antigen presentation leading to CTL responses during viral infection was likewise restricted to the MHC haplotype of professional APCs.

Since immunization with soluble recombinant NP protein did not induce MHC class Irestricted CTL responses or protection against cross-strain virus challenge $(4,28)$, the molecular form of NP or the means by which NP is transferred might be different from the soluble NP protein when injected. The antigen transfer we observed after myoblast transplantation provides further evidence for MHC class I-associated antigen processing and presentation such as the proposed mechanism known as cross-priming $(11,13,29,30)$. This transfer of antigen may be an important alternative to the generally accepted rule that only endogenously produced antigens will be processed and presented via the MHC class I-restricted pathway $(6,7)$. Although the observation that priming of CTL in influenza virus-infected chimeras depends on antigen presentation by the donor BM-derived APCs and may reflect infection of APCs, it is also possible that transfer of antigen from the infected respiratory epithelial cells occurs in a manner analogous to the transfer from myocytes to APCs. The efficacy of induction of cross-strain protective immunity by DNA vaccination suggests a physi- ological significance of such a mechanism in priming CTL responses.

In summary, we demonstrated definitively that myocytes, though shown to produce antigen following DNA injection, are not antigen-presenting cells for induction of CTL responses, and that BM-derived professional APCs are required for generating CTL. We further showed that antigen produced by the myocyte in situ can be transferred to BM-derived APCs for induction of CTL responses, thus indicating that direct transfection of professional APCs is not required. These findings strongly implicate cross-priming as a mechanism for priming CTL responses by DNA vaccination. The finding that induction of CTL during an influenza infection also depends on the MHC haplotype of the BM-derived APCs further suggests the significance of this pathway in generating CTL responses for both infection and immunization.

\section{ACKNOWLEDGMENT}

The authors thank Dr. J. W. Shiver for his helpful discussions.

\section{REFERENCES}

1. Donnelly JJ, Ulmer JB, Liu MA. (1994) Immunization with DNA. J. Immunol. Methods 176: 145-152.

2. Donnelly JJ, Ulmer JB, Shiver JW, Liu MA. (1997) DNA vaccines. Annu. Rev. Immunol. 15: 617-648.

3. Ulmer JB, Donnelly JJ, Parker SE, Rhodes GH, Felgner PL, Dwarki VJ, Gromkwoski SJ, Deck RR, DeWitt CM, Friedman A, Hawe LA, Leander KR, Martinez D, Perry HC, Shiver JW, Montgomery DL, Liu MA. (1993) Heterologous protection against influenza by injection of DNA encoding a viral protein. Science 259: 1745-1749.

4. Ulmer JB, Deck RR, DeWitt CM, Donnelly JJ, Liu MA. (1996) Generation of MHC class I-restricted cytotoxic T lymphocytes by expression of a viral protein in muscle cells: Antigen presentation by non-muscle cells. Immunology 89: 59-67.

5. Fu T-M, Friedman A, Ulmer JB, Liu MA, Donnelly JJ. (1997) Protective cellular immunity: Cytotoxic T-lymphocyte responses against dominant and recessive epitopes of influenza virus nucleoprotein induced by DNA immunization. J. Virol. 71: 2715-2721.

6. Yewdell JW, Bennink JR. (1992) Cell biology 
of antigen processing and presentation to major histocompatibility complex class I molecule-restricted T lymphocytes. $A d v$. Immunol. 52: 1-123.

7. Germain RN. (1994) MHC-dependent antigen processing and peptide presentation: Providing ligands for $\mathrm{T}$ lymphocyte activation. Cell 76: 287-299.

8. Wolff JA, Malone RW, Williams P, Chong W, Acsadi G, Jani A, Felgner PL. (1990) Direct gene transfer into mouse muscle in vivo. Science 247: 1465-1468.

9. Goebels N, Michaelis D, Wekerle H, Hohlfeld R. (1992) Human myoblasts as antigen-presenting cells. J. Immunol. 149: 661-667.

10. Hohlfeld R, Engel AG. (1994) The immunobiology of muscle. Immunol. Today 15: 269274.

11. Bevan MJ. (1995) Antigen presentation to cytotoxic T lymphocytes in vivo. J. Exp. Med. 182: 639-641.

12. Montgomery DL, Shiver JW, Keander KR, Perry HC, Friedman A, Martinez D, Ulmer JB, Donnelly JJ, Liu MA. (1993) Heterologous and homologous protection against influenza virus A by DNA vaccination: Optimization of DNA vectors. DNA Cell Biol. 12: 777-783.

13. Huang AYC, Golumbek $P$, Ahmadzadeh $M$, Jaffee E, Pardoll D, Levitsky H. (1994) Role of bone marrow-derived cells in presenting MHC class I-restricted tumor antigens. Science 264: 961-965.

14. Wysocki LJ, Sato VL. (1978) "Panning" for lymphocytes: A method for cell selection. Proc. Natl. Acad. Sci. U.S.A. 75: 2844-2848.

15. Sentman CL, Kumar V, Koo G, Bennet $M$. (1989) Effector cell expression of NK1.1, a murine natural killer cell-specific molecule, and ability of mice to reject bone marrow allografts. J. Immunol. 142: 1847-1852.

16. Fink PJ, Bevan MJ. (1978) H-2 antigens of the thymus determine lymphocyte specificity. J. Exp. Med. 148: 766-775.

17. Zinkernagel RM, Callahan GN, Klein J, Dennert G. (1978) Cytotoxic T cells learn specificity for self $\mathrm{H}-2$ during differentiation in the thymus. Nature 271: 251-253.

18. Sprent J, Lo D, Gao E-K, Ron Y. (1989) T cell selection in the thymus. Immunol. Rev. 10: 57-61.

19. Huang AYC, Bruce AT, Pardoll DM, Levitsky HI. (1996) In vivo cross-priming of MHC

Communicated by H. Wigzell. Accepted April 8, 1997. class I-restricted antigens requires the TAP transporter. Immunity 4: 349-355.

20. Falk K, Rötzschke O, Stevanovic S, Jung G, Rammensee HG. (1991) Allele-specific motifs revealed by sequencing of self-peptides eluted from MHC molecules. Nature 351: 290-296.

21. Rammensee H-G, Falk K, Rötzschke O. (1993) Peptides naturally presented by MHC class I molecules. Annu. Rev. Immunol. 11: 213-244.

22. Barr E, Leiden JM. (1991) Systemic delivery of recombinant proteins by genetically modified myoblasts. Science 254: 1507.

23. Guéry J-C, Ria F, Adorini L. (1996) Dendritic cells but not B cells present antigenic complexes to class II-restricted $\mathrm{T}$ cells after administration of protein in adjuvant. J. Exp. Med. 183: 751-757.

24. Nair S, Babu JS, Dunham RG, Kanda $P$, Burke RL, Rouse BT. (1993) Induction of primary, antiviral cytotoxic, and proliferative responses with antigens administered via dendritic cells. J. Virol. 67: 4062-4069.

25. Doe B, Selby M, Barnett S, Baenziger J, Walker CM. (1996) Induction of cytotoxic T lymphocytes by intramuscular immunization with plasmid DNA is facilitated by bonemarrow-derived cells. Proc. Natl. Acad. Sci. U.S.A. 93: 8578-8583.

26. Condon C, Watkins SC, Celluzzi CM, Thompson K, Falo LD Jr. (1996) DNA-based immunization by in vivo transfection of dendritic cells. Nat. Med. 2: 1122-1128.

27. Corr M, Lee DJ, Carson DA, Tighe H. (1996) Gene vaccination with naked plasmid DNA: Mechanism of CTL priming. J. Exp. Med. 184: 1555-1560.

28. Donnelly JJ, Ulmer JB, Liu MA. (1995) Protective efficacy of intramuscular immunization with naked DNA. In: Liu MA, Hilleman MR, Kurth $\mathrm{R}$ (eds). DNA Vaccines: A New Era in Vaccinology. The New York Academy of Sciences, New York, pp. 40-46.

29. Bevan MJ. (1976) Minor H antigens introduced on $\mathrm{H}-2$ different stimulating cells cross-react at the cytotoxic $\mathrm{T}$ cell level during in vivo priming. J. Immunol. 117: 2233-2238.

30. Gooding LR, Edwards CB. (1980) H-2 antigen requirements in the in vitro induction of SV40-specific cytotoxic T lymphocytes. J. Immunol. 124: 1258-1262. 